\title{
Development of Mathematical Test Instrument to Measure Critical Thinking Ability
}

\author{
Dafid Slamet Setiana ${ }^{1}$, ZainnurWijayanto ${ }^{2}$, I Nyoman Arcana ${ }^{3}$ \\ (dafid.setiana@ustjogja.ac.id ${ }^{1}$, zainnurw@ustjogja.ac.id ${ }^{2}$, nyoman.arcana@ustjogja.ac.id ${ }^{3}$ )
}

Universitas Sarjanawiyata Tamansiswa ${ }^{123}$

\begin{abstract}
The purpose of this study was to describe the development stages of mathematical test instruments to measure critical thinking skills and produce valid, practical and effective mathematical test instruments to measure critical thinking skills. The developmental model used in this study was a model developed by Borg \& Gall as the major developmental model, modified by Dick \& Carey model and Kemp model. Furthermore, the developmental model is called RRD (Real Research and Development). The research subjects were students of the XII IPA class of six public high schools in Pacitan. Research data was collected through tests and interviews. The data was analyzed using content analysis and descriptive analysis techniques. This research produced a mathematical test instrument to measure critical thinking skills. The results of the analysis show that the product meets the validity, practicality, and effectiveness criteria.
\end{abstract}

Keywords: Test Instruments, Mathematics, Critical Thinking

\section{Introduction}

Education has a fundamental role in a nation. Education must be developed continuously in accordance with the times. Quality education is education that can bring students to achieve educational functions and goals. Efforts to improve the quality of education are things that cannot be negotiated in order to improve the quality of Indonesia's human resources.

In addition to realizing quality human beings, education is also an integral part of development. Quality human beings can be the driving force for achieving development progress. Based on this, it is clear that education has a purpose to form advanced people. Along with the goal of improving human quality, schools as formal institutions have functions and responsibilities in realizing a good and quality education process. Therefore, various components of education in schools must function optimally.

The quality of Indonesian education is still far compared with neighbor countries. Based on the results of studies of international institutions shows that Indonesian students' mathematics literacy is still low compared to other countries. It was based on the study of Trends in International Mathematics and Science Study (TIMSS) and Program for International Student Assessment (PISA) which put Indonesia at the bottom position, which was ranked on 45 from 50 participating countries in TIMSS [1] and in the rank of 63 from 70 countries in PISA. 
The low achievements in mathematics based on the TIMSS and PISA related to the Indonesian students are not able to do the TIMSS and PISA tests well. The results of the analysis indicate that the cause of it is most of the tested questions are included in the category of non-routine questions. That is, to solve it needed further thought because the procedure is not as clear or unlike the procedures studied in the class [2]. Indonesian students were not trained to do non-routine questions. Learning was still dominated by simple problems, in terms of problems with a clear solution, namely the problem with a single solution. It was not open-ended. It could be said as a routine question, which the exercise question could be solved by the procedures learned in the classroom [2]. As a result, Indonesian students are weak to think critically in identifying new problems, to seek and develop materials or ideas, and to solve them uses settlement procedures. The various abilities of high-level thinking, are significant difficulties in thinking critically.

Critical thinking was a way of thinking, and a set of skills, to encourage an informed, conscious, systemic, considered and logical approach to decide what to be believed or done. Critical thinking led to valid arguments and conclusions. It reinforced to criticism [3]. Critical thinking was also defined as a process of active intellectual discipline, and skilled conceptualization in applying, analyzing, synthesizing, and/or evaluating collected or generated information through observation, experience, reflection, reasoning, or communication, as a set of guides to have a belief and some [4].

Critical thinking is a learned skill that requires instruction and practice [5]. Because critical thinking is a mental habit that requires students to think about their thinking and about improving the process, it requires students to use higher order thinking skills not memorize data or accept what they read or are told without critically thinking about it [6]. Therefore, critical thinking is a product of education, training, and practice [5].

According to Facione [7], the most basic concept of critical thinking is the ability of interpretation, analysis, evaluation, inference, explanation, and self-regulation. While critical thinking skills by Onosko and Newmann [8] may challenge the students to interpret, analyze or manipulate information. Therefore, the critical thinking skills needed when we try to understand something of information that will be used for the triggering of ideas [8]. Similarly, critical thinking requires a student to use new information or manipulate existing knowledge and information so as to obtain reasonable responses to new situations [9] [10]. Ennis [8] opined that critical thinking is reflective thinking that focused on patterns of decision making about what must be believed and what must be done. In the context of mathematical problem solving, Krulik and Rudnick [11] stated that critical thinking is analytical thinking and reflection that involving testing activities, questioning, connecting and evaluating all aspects of a situation or problem. Critical thinking skills are very important in mathematics learning because these skills can improve the quality of mathematics learning in better and meaningful, so, therefore, should be a systematic way to develop such skills through mathematics learning in school [12].

Based on some previous definitions, it can be concluded that critical thinking is a process of applying, analyzing, synthesizing, and/or evaluating collected or generated information through observation, experience, reflection, reasoning, or communication, to have a result in valid and strong arguments and conclusions resistant to be criticism.

Critical thinking skill was important because it enabled students to deal effectively with social, scientific, and practical problems [13]. Simply it puts, students, to be able to think critically and to the solve problems effectively. Having knowledge or information is not enough. To be effective in the workplace (and in their personal lives), is needed. Students 
must be able to solve problems to make effective decisions, and they must be able to think critically.

The concept of mathematics is obtained because the thinking process, so that the skills of deep thinking (critical thinking) need to be developed in the learning of mathematics. This is in accordance with the objectives of school mathematics education which emphasizes the arrangement of children's reasoning and the formation of children. Therefore in the process of learning mathematics, it is influenced by the ability to think. Where mathematics material and critical thinking skills are two things that cannot be separated because the mathematical material is understood through critical thinking and critical thinking trained through learning mathematics. The mathematical material is composed of interrelated concepts. To solve a mathematical problem, one or more concepts are needed. To be able to understand mathematical concepts and solve a problem, it is necessary to have the ability to think critically, without the ability to think critically students will not be able to solve problems and understand mathematical concepts maximally. Conversely, to be able to have critical thinking skills, one of them can be trained through learning mathematics, by solving open-ended problems. Thus it is clearly seen that there is a relationship between the mathematics learning process and critical thinking.

Critical thinking is so important. So, it needs to know the level of critical thinking of students. By knowing the level of critical thinking students can be used as guidelines by educators to formulate an action related to the learning process that will be implemented. The measurement of critical thinking skills can be carried out using a test instrument that includes completion steps and indicators of critical thinking.

The main critical thinking theory used in the preparation of this test instrument is the critical thinking indicator developed by Ennis. Ennis [8] describes that critical thinking as a process that the aims were to make reasonable decisions so that the thinking was to be best about the truth that is done rightly. There were six basic elements to be considered in critical thinking are synchronized with FRISCO, namely Focus, Reason, Inference, Situation, Clarify, and Overview. Ennis also mentioned that critical thinking skills related to mathematics learning in the classroom. It was divided into two indicators, namely the general indicator and indicators that related to the content [8]. But in a line of indicators, these indicators could be grouped into five major activities, namely: elementary clarification, basic support, interference, advanced clarification, and strategy and tactics.

Another applied theory was Bloom's Taxonomy [14] which had been revised by Anderson \& Krathwohl [15] which contained six stages of thinking: a) a) remembering, b) understanding, c) applying, (d) analyzing, e) evaluating, and f) creating. The compilation of questions is used by the Krulik and Rudnick Theory regarding the development of students' critical thinking skills by answering innovative questions, including: Are there other ways? (What's another way?) What if ...? (What if ...?) Which is wrong? (What's wrong?), And what will be done? (What would you do?) [11].

From the description above, the authors intend to conduct research on the development of mathematical test instruments to measure critical thinking skills. The research problems are: 1) How to develop the mathematics test instruments to measure critical thinking skills? and 2) How is the valid, practical, and effective mathematics test instrument to measure critical thinking skills? Whereas the aim to be achieved in this study is to describe the stages of developing a mathematical test instrument to measure critical thinking skills and produce a valid, practical and effective mathematical test instrument to measure critical thinking skills. 


\section{Method}

This research is a research or development $(\mathrm{R} \& \mathrm{D})$ research. The development model used in this study is a model developed by Borg \& Gall [16] a major development model, which is modified with several other models such as Dick \& Carey's model [17]and Kemp's model [18]. Further modification of the development model resulted in a new development model called RRD (Real Research and Development). The study was conducted in October December 2016. The research locations were in six schools in Pacitan, They were SMA N 2 Pacitan, SMA N Punung, SMA N, SMA N 1 Ngadirojo, SMA N 2 Ngadirojo, and SMA N Tegalombo. The research subjects of the research were the students of class XII IPA in 6 (six) senior high schools in Pacitan, East Java. In each school, the random sampling techniques were used

\subsection{Procedure}

The RRD (Real Research and Development) development model includes 5 main stages, namely:

2.1.1 Collecting information, it consisted of the planning that including the definition of ability and the formulation of objectives

2.1.2 Developing the product, namely the preparation of test instruments

2.1.3 Testing the preliminary and revision, at this stage, the file was sent to the validator to get the validation by some revisions given and then corrected

2.1.4 Testing the operational test and its revision, this stage was a test phase at schools that had been determined, then the final product revision is carried out

2.1.5 Doing dissemination and implementation, it disseminated the final product that had been tested

\subsection{Data, Instruments and Data Collection Techniques}

The research data were qualitative and quantitative data. Qualitative data was collected through a validation sheet. The quantitative data was collected using critical thinking skills testing instruments and practicality assessment instruments.

The technique of collecting data was through observation at the time of the operational test. Interviews and data collection through questionnaires were conducted after the operational tests. Interviews were conducted to the subjects of teachers and some students. The questionnaire was given to all of the students as the research subjects. The critical thinking skills test was held in the last meeting.

Table 1. A grid of Critical Thinking Ability Test instruments

\begin{tabular}{|c|c|c|}
\hline \multicolumn{3}{|c|}{ Critical Thinking Aspects } \\
\hline Aspects & Indicator & Sub-indicator \\
\hline Provide a simple explanation & Focus questions & Identify questions \\
\hline of [Focus] & $\begin{array}{l}\text { Ask questions, answer questions, } \\
\text { clarify challenging questions }\end{array}$ & Provide a simple explanation \\
\hline $\begin{array}{l}\text { Building basic skills } \\
\text { [Reason (Reason)] }\end{array}$ & $\begin{array}{l}\text { Consider whether the source can be } \\
\text { trusted or not }\end{array}$ & $\begin{array}{l}\text { Use existing procedures to } \\
\text { determine results } \\
\text { Be careful }\end{array}$ \\
\hline
\end{tabular}




\begin{tabular}{lll}
\hline Summing up [Inference] & $\begin{array}{l}\text { Inducing, considering the results of } \\
\text { induction } \\
\text { Making and reviewing the values of } \\
\text { consideration }\end{array}$ & Make conclusions \\
Arovide further explanation & $\begin{array}{l}\text { Defining terms, considering } \\
\text { definitions }\end{array}$ & $\begin{array}{l}\text { Consider the definition of } \\
\text { working on the problem }\end{array}$ \\
$\begin{array}{l}\text { [Situation and Clarify] } \\
\text { Managing strategies and } \\
\text { tactics [Overview] }\end{array}$ & Determine actions & $\begin{array}{l}\text { Combining several concepts to } \\
\text { solve problems }\end{array}$ \\
\hline
\end{tabular}

\subsection{Data analysis technique}

The data that have been collected were analyzed through two techniques, they were the content analysis and the descriptive analysis. Content analysis was primarily to analyze the obtained data of the results of the experts'reviews and the mathematics subject teachers. Data in the form of numbers were interpreted in accordance with the meaning that had been set and given the assessment in accordance with the predetermined criteria. The data in the form of sentences were grouped and simplified, and then they were coded. Interview data are analyzed and interpreted according to the stated research objectives. Quantitative research data was analyzed by describing the data based on the performance category of every aspect of critical thinking which served to explain the effectiveness of the test instrument.

2.3.1 Validity Test of Product

The test instrument developed is said to be valid, if all aspects of the validity assessment are declared valid by the validator. Thus, if the results of data analysis do not meet the valid categories in this study will be taken into consideration to revise the test instruments before being tested.

2.3.2 Practicality Test of Product

Data on the practicality of the products developed consisted of data from teacher assessment and student assessment. In general, the analysis of the data is done by grouping the data and then calculating the average score.

\subsubsection{Effectiveness Test of Product}

Data analysis of product effectiveness is carried out on the results of students' critical thinking skills tests. The results of the test of critical thinking skills are said to be completed individually if it reaches the Minimum Completeness Criteria (KKM) set by the school which is 75.00 . Classical completeness is achieved if a minimum of $75 \%$ of students achieves individual completeness criteria so that it can be said to be an effective mathematical test instrument. In addition to classical mastery, the test results are also analyzed based on each aspect of critical thinking skills. Criteria for critical thinking skills based on test results can be seen in Table 2 below.

Table 2. Criteria for Critical Thinking Ability Based on Test Results

\begin{tabular}{lll}
\hline Criteria & Value & Interval Value \\
\hline A & $80,0<\bar{M} \leq 100,0$ & very good \\
B & $60,0<\bar{M} \leq 80,0$ & good \\
C & $40,0<\bar{M} \leq 60,0$ & enough \\
D & $20,0<\bar{M} \leq 40,0$ & less \\
E & $0,0<\bar{M} \leq 20,0$ & very less \\
\hline
\end{tabular}


The test instrument is to meet the effectiveness criteria if the average value of each aspect of critical thinking ability as a whole has at least reached the "good" criteria.

\section{Results and discussion}

Data analysis in this study consisted of the validity of data analysis, practicality data analysis, and data analysis on the effectiveness of mathematical test instruments to measure critical thinking skills.

3.1 Validity Analysis of Mathematical Test Instruments

Based on the results of the validation of the expert, it is known that the feasibility of the mathematical test instrument developed. The results of the validation of mathematics test instruments to measure critical thinking skills can be seen in Table 3.

Table 3. Validation Results Mathematical test instruments

\begin{tabular}{llll}
\hline Numb. & Product & $\begin{array}{l}\text { Evaluation of } \\
\text { Feasibility }\end{array}$ & Validity \\
\hline 1. & Test instrument & Valid & Worth using with minor revisions \\
2. & Interview guidelines & Valid & Worth using with minor revisions \\
\hline
\end{tabular}

Based on Table 3 it can be seen that the overall validator's assessment is valid. Mathematical test instruments are ready for use after several revisions are made based on comments and suggestions for improvement from the validator.

3.2 Practicality Analysis of mathematical test instruments

The practicality of mathematics test instruments to measure critical thinking skills in this study is based on data from teacher assessment and student assessment results.

3.2.1 Analysis of Teacher Assessment Data

The results of the teacher's assessment of the practicality of the developed mathematics test instruments can be seen in Table 4 below:

Table 4. Results of Teacher's Assessment of Practical Mathematics test instruments

\begin{tabular}{lll}
\hline Products & Average & Category \\
\hline Test instrument & 49,17 & Very easy to implement \\
\hline
\end{tabular}

Based on Table 4 it can be seen that the average product score is in the "very easy to implement" category. This means a mathematical test instrument developed practically for use.

\subsubsection{Analysis of Student Assessment Data}


The results of students' assessment of the practicality of the developed mathematical mathematics test instruments can be seen in Table 5 .

Table 5. Analysis of Student Assessment Results on Practical Mathematics test instruments

\begin{tabular}{lll}
\hline Numb. & School Name & $\begin{array}{l}\text { Percentage of students in the } \\
\text { minimum category "easy to use" }\end{array}$ \\
\hline 1 & SMA N 2 Pacitan & $100 \%$ \\
2. & SMA N Punung & $100 \%$ \\
3. & SMA N Tulakan & $100 \%$ \\
4. & SMA N 1 Ngadirojo & $100 \%$ \\
5. & SMA N 2 Ngadirojo & $100 \%$ \\
6. & SMA N Tegalombo & $100 \%$ \\
\hline
\end{tabular}

Based on Table 5, it can be seen that the average percentage of students in all schools that assess mathematics test instruments to measure critical thinking skills in the minimum category "easy to implement" is $100 \%$. This means that mathematical test instruments are developed practically because the percentage has exceeded $75 \%$.

Based on these data, it can be concluded that the developed mathematics test instruments meet practical criteria. Moreover, the results of the analysis show that the average teacher's assessment of the mathematics test instruments developed is in the "very easy to implement" category. Thus the product practicality criteria are very easy to implement.

3.2.3 Effectiveness Analysis of Instruments

The effectiveness of developed mathematics test instruments is measured based on the results of students' critical thinking skills. The test is based on a test grid that refers to indicators of critical thinking ability. The test results show that the average value obtained by students is 86.51 and the overall value of students has reached a predetermined KKM. This means that all students have achieved individual completeness, so the classical percentage of completeness is $100 \%$. This can already be said to be an effective test instrument developed because the percentage of classical completeness in the critical thinking ability test results has exceeded $75 \%$.

Besides the general values, the test results are also assessed based on aspects of critical thinking skills, the results can be seen in Table 6 .

Table 6. Critical Thinking Ability Test Results Based on Critical Thinking Aspects

\begin{tabular}{|c|c|c|c|c|c|c|c|c|c|c|c|}
\hline \multirow{2}{*}{ Schools } & \multicolumn{11}{|c|}{ Sub-indicators } \\
\hline & 1 & 2 & 3 & 4 & 5 & 6 & 7 & 8 & 9 & 10 & 11 \\
\hline SMA N 2 Pacitan & 93,2 & 81,8 & 97,1 & 77,5 & 72,1 & 96,4 & 91,4 & 100 & 89,3 & 100 & 71,8 \\
\hline SMA N Punung & 92,4 & 84,3 & 98,1 & 77,1 & 79,5 & 97,1 & 90,5 & 100 & 90,5 & 100 & 71,4 \\
\hline SMA N Tulakan & 95,5 & 84,1 & 96,4 & 78,2 & 70,0 & 90,0 & 88,2 & 100 & 84,5 & 100 & 71,8 \\
\hline SMA N 1 Ngadirojo & 95,0 & 81,3 & 96,7 & 77,1 & 76,3 & 95,8 & 86,7 & 100 & 88,3 & 100 & 75,4 \\
\hline SMA N 2 Ngadirojo & 90,0 & 80,0 & 97,4 & 71,7 & 68,7 & 96,5 & 93,0 & 100 & 90,4 & 100 & 71,3 \\
\hline SMA N Tegalombo & 93,0 & 73,5 & 100 & 75,7 & 70,4 & 93,0 & 98,3 & 100 & 88,7 & 100 & 73,9 \\
\hline
\end{tabular}




\begin{tabular}{|c|c|c|c|c|c|c|c|c|c|c|c|}
\hline Average & 93,2 & 80,8 & 97,6 & 76,2 & 70,4 & 94,9 & 91,3 & 100 & 88,7 & 100 & 72,6 \\
\hline Criteria & $\begin{array}{l}\text { Very } \\
\text { good }\end{array}$ & Good & $\begin{array}{l}\text { Very } \\
\text { good }\end{array}$ & Good & Good & $\begin{array}{l}\text { Very } \\
\text { good }\end{array}$ & $\begin{array}{l}\text { Very } \\
\text { good }\end{array}$ & $\begin{array}{l}\text { Very } \\
\text { good }\end{array}$ & $\begin{array}{l}\text { Very } \\
\text { good }\end{array}$ & $\begin{array}{l}\text { Very } \\
\text { good }\end{array}$ & Good \\
\hline
\end{tabular}

Aspect Description:

a.
b.
c.
d.
e.
f.
g.
h.
i.
j.
k.

Write things that are known and problems based on questions

Painting geometric shapes based on questions

Paint the transformation line

Painting transformation results

Solve problems with the right and coherent steps

Make conclusions

Provide an explanation of the conclusions written

The principle of transformation

The principle of substitution

Consider the definition of transformation

Using a substitution procedure to determine the shadow equation

Measurement Analysis of Critical Thinking Ability

The results of measuring critical thinking skills based on test results are presented in Table 7 and Figure 1 below.

Table 7. Results of Measurement of Critical Thinking Ability

\begin{tabular}{lllll}
\hline \multirow{2}{*}{ Schools } & \multicolumn{3}{l}{ Critical Thinking Ability } & \\
\hline SMA N 2 Pacitan & 18 students & $64,29 \%$ & 10 students & $35,71 \%$ \\
SMA N Punung & 14 students & $66,67 \%$ & 7 students & $33,33 \%$ \\
SMA N Tulakan & 14 students & $63,64 \%$ & 8 students & $36,36 \%$ \\
SMA N 1 Ngadirojo & 17 students & $70,83 \%$ & 7 students & $29,17 \%$ \\
SMA N 2 Ngadirojo & 14 students & $60,87 \%$ & 9 students & $39,13 \%$ \\
SMA N Tegalombo & 16 students & $69,57 \%$ & 7 students & $30,43 \%$ \\
\hline
\end{tabular}

Measurement Chart of Critical Thinking Ability

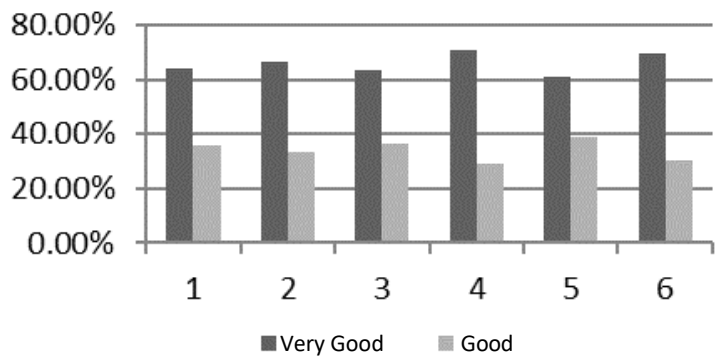

Figure 1. Measurement Chart of Critical Thinking Ability

Information:

1: SMA N 2 Pacitan 4: SMA N 1 Ngadirojo

2: SMA N Punung 5: SMA N 2 Ngadirojo

3: SMA N Tulakan 6: SMA N Tegalombo 


\section{Conclusions And Suggestions}

\subsection{Conclusion}

Based on the results of research and discussion, conclusions can be obtained that (1) this research develops an instrument of high school mathematics tests for class XII majoring in science to measure critical thinking skills, (2) Mathematical test instruments were developed using the Borg \& Gall development model as the major developmental model, modified by Dick \& Carey model and the Kemp model. Furthermore, the developmental model is called RRD (Real Research and Development). The model includes five stages, they are: collecting information, developing the product, testing the preliminary and revision, testing the operational test and its revision, as well as data collection, dissemination, and implementation. The conclusion is also produced a mathematical test instrument to measure critical thinking skills. The results of the analysis show that the product meets the validity, practicality, and effectiveness criteria. After going through the validation stage by experts, the products developed are included in the validity category. Products that have been carried out preliminary tests and operational tests are included in the practicality criteria. This is based on the results of student assessment that shows the product has met the practicality criteria as well as the teacher's assessment results that show the product included in the criteria "very easy to use".Products that had been carried out preliminary tests and operational tests are included in the effectiveness criteria. This is based on the results of the test of students' critical thinking skills obtained by the percentage of classical completeness has exceeded $75 \%$. Based on aspects of critical thinking skills as a whole it is known that the average value of each aspect has reached the criteria of "high". Thus it can be said that a mathematical test instrument for measuring critical thinking skills is effective.

\subsection{Suggestion}

The suggestions for the use of the products developed are: (1) mathematical test instruments to measure critical thinking skills had been tested for feasibility because they have met the validity, practicality, and effectiveness criteria, so that they can be used to measure students' critical thinking skills in other schools, especially the XII science class, and (2) development of mathematical test instruments to measure critical thinking skills is only carried out on students of class XII Science in geometry transformation material. For other researchers, it is advisable to develop mathematical test instruments to measure the ability to think critically on other material and levels. 


\section{References}

[1] TIMSS: TIMSS 2015 International results in mathematics. Chestnut Hill: TIMSS \& PIRLS International Study Center. (2015)

[2] Nyimas, A., et.al.: Development of elementary school mathematics learning. Depdiknas, Jakarta. (2007)

[3] Onions, P. E. W.: Thinking critically: An introduction, working paper. http://www.patrickonions.org/docs/academic/2009\%20Thinking\%20critically.pdf. (2009)

[4] Scriven, M., \& Paul, R.: The Critical Thinking Community: Foundation for Critical $\begin{array}{lllll}\text { Thinking. } & \text { Defining } & \text { critical thinking. } & 5 & \text { Mei }\end{array}$ http://www.criticalthinking.org/aboutCT/define_critical_thinking.cfm. (2007).

[5] Snyder, L., Snyder, M.: Teaching Critical Thinking and Problem-Solving Skills. The Delta Pi Epsilon Journal, Volume L, No. 2, pp. 90-99. Spring/Summer (2008)

[6] Tempelaar, D. T.: The role of metacognition in business education. Industry and Higher Education, Vol. 20(5), pp. 291-297 (2006)

[7] Facione, P. A.: Critical thinking: what it is and why it counts. Insight Assessment. California: California Academic Press. pp. 1-22 (2006)

[8] Ennis, R. H.: Critical thinking. Prentice Hall, Inc., New Jersey (1996)

[8] Onosko, J.J. and Newmann, F.M.: Creating more Thoughtful Learning Environments. In Dim J.N. Mangieri and C. Block (Eds.). Creating powerful thinking in teachers and students: Diverse Perspectives. Fort Worth, TX: Harcourt (1994)

[9] Lewis, A. and Smith, D.: Defining Higher Order Thinking. Theory into Practice, Vol. 32(3), pp. 131-137 (1993)

[10] Perkins, C., and Murphy E.: Identifying and measuring individual engagement in critical thinking in online discussions: An exploratory study. Educational Technology \& Society, Vol. 9(1), pp. 298-307. (2006)

[11] Krulik, S. \& Rudnick.: Innovative task to improve critical and creative thinking skills. Developing Mathematical Reasoning in Grades K-12, pp.138-145 (1999)

[12] Cobb, P., Wood, T., Yackel, E. and McNeal, B.: Characteristics of classroom mathematics tradition: an interactional analysis. American Educational Research Journal, Vol. 29, pp. 573-604 (1992)

[13] Shakirova, D. M.: Technology for the shaping of college students' and upper-grade students' critical thinking. Russian Education \& Society, Vol.49(9), pp. 42-52 (2007)

[14] Bloom, B.: Taxonomy of educational objectives. David McKay Co. Inc., New York (1956)

[15] Anderson, L. \& Krathwohl, D., et al. (Eds.): A taxonomy for learning, teaching and assessing: a revision of Bloom's taxonomy of educational objectives. Longman, New York (2001)

[16] Borg, W.R. \& Gall, M.D.: Educational research: An introduction (4th ed.). Longman, Inc., New York (1983)

[17] Dick, W., Lou, C., Carey, \& James, O.: The systematic design of instruction (7th ed). Longman, New York (2005)

[18] Kemp, J. E., Morrison, G. R., \& Ross, S. V.: Design effective instruction. Mcmillan, New York (1994) 